\title{
THE PRACTICAL IMPORTANCE OF ACCOUNTING EDUCATION FOR FUTURE MANAGERS
}

\author{
Nataliia Radionova, DSc. \\ Kyiv National University of Technologies and Design - Kyiv (Ukraine) \\ Dr. Radostina Stoyanova, Assist. Prof. \\ Institute for Bulgarian Language "Prof. Lyubomir Andreychin" \\ Bulgarian Academy of Sciences (Bulgaria)
}

\begin{abstract}
There is an opinion that accounting is a work on the chronological processing of the data of business transactions that have already occurred at the enterprise. Many applicants are not interested in the accounting profession, considering it narrowly focused, boring, and unprestigious. Although, graduates of accounting specialties have applied knowledge and the ability to implement them in their specialty, as accounting is required by all business entities, without exception, from an individual entrepreneur to transnational corporations. Knowledge and skills in accounting disciplines allow graduates to choose a large number of specialties from an accountant to a financial director or an auditor. Thus, the subject of the research is a set of theoretical and methodological issues regarding the importance of accounting knowledge for managers of various levels of enterprise administration. The purpose of the article is a theoretical justification of the methodological aspects of the importance of acquiring accounting competencies by managers of enterprises.

Keywords: knowledge of accounting; analysis and audit; accounting education; accountancy; enterprise management.
\end{abstract}

\section{Introduction}

In modern business conditions, the proof of professional competence of the accountant already is not only providing interested users with high-quality, reliable and timely information about the activities of the enterprises in retrospect, but also helping the manager with thorough recommendations to improve the company's performance in the future. The formation of such skills is possible through the acquisition of modern accounting knowledge. Establishing an effective long-term business is impossible without such important functional components of management as accounting, analysis and control.

Rational management increases the economic stability and profitability of the enterprise and, as a consequence, strengthens its ability to protect its market inter- 
ests and the ability, other things being equal, to make more profit than competitors. Therefore, the main purpose of management is to achieve the planned results of the enterprise in the most economical way (Garrison, Norren \& Brewer 2006, 368).

\section{Systematic approach to enterprise management}

Note that in terms of management, the enterprise appears as the unity of two organizational systems: managing and managed.

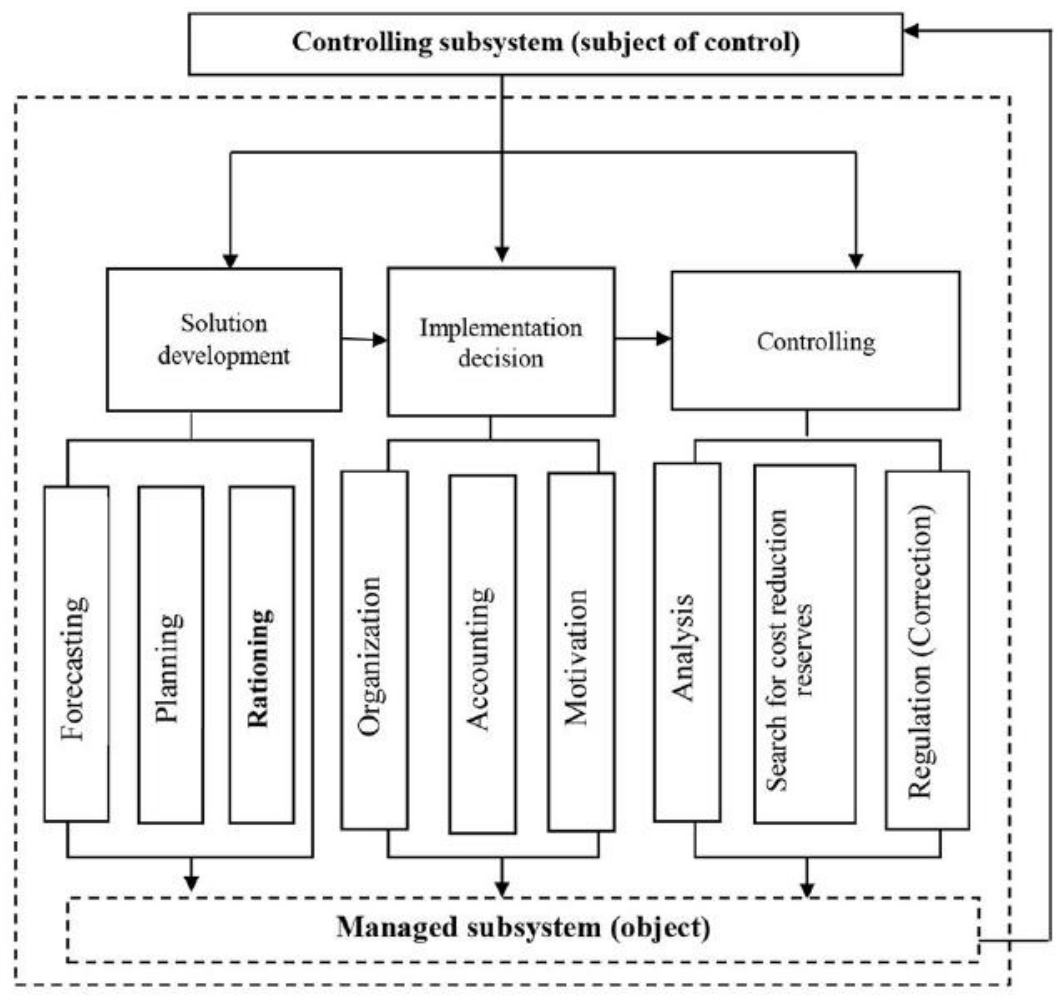

Fig. 1. The scheme of implementation of the enterprise management cycle

Source: developed by the authors

The analysis of the management process shows that it is aimed at achieving the ultimate goals of the enterprise through certain ways and methods of influencing the managing subsystem on the managed subsystem. Thus, the purposefulness of the management is determined by its purpose, which is achieved as a result of solving problems and performing management functions. According to the existing approaches to the management process, the general algorithm for the 
implementation of management functions can be represented in the form of the scheme (Fig. 1).

It should be noted that the management of the enterprise takes place in stages, and each of these stages has its own content related to the main processes of enterprise management (table 1). As can be seen from table. 1, enterprise management involves the implementation of such stages as the development (adoption) and implementation of decisions, as well as monitoring their implementation.

Table 1. The content of the main stages of the enterprise management process

\begin{tabular}{|c|c|c|}
\hline $\begin{array}{c}\text { Stage of the } \\
\text { enterprise } \\
\text { management } \\
\text { process }\end{array}$ & $\begin{array}{c}\text { Functional components } \\
\text { of each stage }\end{array}$ & The content of the stages of the management \\
process \\
$\begin{array}{c}\text { Solution } \\
\text { development }\end{array}$ & $\begin{array}{c}\text { Prognostication } \\
\text { Planning } \\
\text { Rationing }\end{array}$ & $\begin{array}{c}\text { Forecasting the profitability of the enterprise, } \\
\text { determining targets, setting cost standards } \\
\text { for all types of resources and centers of } \\
\text { responsibility }\end{array}$ \\
\hline $\begin{array}{c}\text { Implementation } \\
\text { of solutions }\end{array}$ & $\begin{array}{c}\text { Organization } \\
\text { Accounting } \\
\text { Motivation }\end{array}$ & $\begin{array}{c}\text { Organization of the production process, } \\
\text { accounting of all business operations, } \\
\text { motivation of employees to optimize work } \\
\text { results }\end{array}$ \\
\hline Control & $\begin{array}{c}\text { Analysis } \\
\text { Search for cost } \\
\text { optimization reserves } \\
\text { Regulation (correction) }\end{array}$ & $\begin{array}{c}\text { Comparison of planned and actual indicators, } \\
\text { analysis of opportunities for improvement of } \\
\text { results, search for opportunities to optimize } \\
\text { costs, taking measures to eliminate deviations }\end{array}$ \\
\hline
\end{tabular}

In its turn, the management stages are realized through the elements (functional components) of the management cycle: forecasting, planning, rationing, administration, accounting, motivation, analysis, search for reserves to optimize costs, regulation.

\section{Consideration of the impact of accounting knowledge on the functional components of the enterprise management process}

At the stage of decision development, in our opinion, the following functional structures should be distinguished: forecasting, planning and rationing.

It is considered appropriate to view the impact of each functional component on the stages of management decision-making.

Solution development begins with forecasting, which involves using both past experience and current assumptions about the future to determine it. The forecasting is based on financial statements prepared by the company's accountant. As a rule, it is advisable to make forecasts of the enterprise for $2-3$ years. The longer forecast period will give significant deviations. The forecasting results are used as a basis for planning (Kobyliukh 2012, 43 - 49). 
Consequently, planning is inseparably linked with forecasting, therefore, the next stage is the development of the production plan, as this plan will determine in the future the level of planned and actual indicators of the enterprise (Dovhan' 2011, 440). The quality of the solution to this issue depends on how correctly the necessary conditions and restrictions are taken into account. In our opinion, when planning, it is necessary to take into account the characteristics of the factors of the enterprise production as well as the data of the accounting documentation: the cost of material resources; price forecasts for manufactured products and the possible volume of their sales.

In addition, the development of effective solutions in the management system will be facilitated by rationing, which is aimed at ensuring the efficient use of the resources on the basis of comprehensive efforts to reduce the total costs of manufacturing and selling products (Dohadaieva 2012, 22 - 24). This can be achieved if, during rationing, the main attention is given to the possibilities of using modern highly efficient equipment and technologies, rational organization of production, labor and management, which would help to reduce the cost of resources and reflect this timely in cost rates. The specialist with an accounting education can easily cope with rationing.

The next step is the implementation of solutions, within which it is proposed to highlight the following functional components: organization, accounting, motivation.

So, for the rational implementation of the decisions made, a proper organization is needed that contributes to the establishment of organizational aspects of the management; definition of relationships, document flow rules, deadlines, ways of implementing solutions etc. As a functional component of the management system, the organization is carried out by a leader, manager or a responsible executor, directed to task distribution in joint activities among the executors and establishing certain relationships between them in activities, which leads to the desired result (Lavryk 2013, 360 - 369). Modern accounting education forms analytical thinking and lays the basis for future specialists could successfully implement organizational aspects at the enterprise. And the establishment of the document flow is a classic competence for accounting specialists.

The implementation of enterprise management decisions is carried out through appropriate business transactions, which must be chronologically systematized, recorded and processed. Therefore, the stage of implementing solutions requires such a functional component as accounting. Accounting education allows graduates to professionally process data on business transactions for their further storaging and reporting, which are useful for management. Besides a standard financial accounting, during their studies, students master the features of accounting in banks, budgetary institutions, transnational corporations. The discipline "Accounting policy of the enterprise" allows students to trace the creation of a rational accounting system at the enterprise, and the knowledge of the discipline "Reporting of the 
enterprise" - not to have problems with tax and other regulatory authorities on the correct preparation of reports.

An important aspect at the stage of the implementing solution is the interest of the employees of the enterprise in increasing the productivity of labor. Therefore, the next functional component of this stage we will define the motivation. Motivation should activate and stimulate such methods of influencing employees, which would induce them not only to keep the costs set by the plan, but also to find opportunities for their optimization. An accounting education provides the knowledge necessary to design the rational system that applies both material and moral incentives.

The third stage of management - the control, which provides: analysis, search for reserves to reduce costs and regulation of activities.

The analysis, which is proposed to consider as a functional component of the control stage, allows to find out the dynamics of income and expenses, trends in the implementation of the plan in terms of profit, the influence of factors on unplanned changes, as well as to identify reserves for increasing profits, reducing costs and to estimate measures to optimize production. For each enterprise from a dozen types of analysis, which differ in depth, degree of detail, covered period, frequency and many other parameters, it is necessary to determine its own set of indicators of economic activity, which will be determined by the individuality of the enterprise's functioning, by the specific method and accuracy of fixing the initial data. This can be easily achieved with an accounting education, which provides for the development of analytical skills. Besides the classical disciplines "Financial Analysis", "Economic Analysis", students study such modern disciplines as "Models and Methods of Decision Making in Analysis and Audit", "Accounting and Information Systems and Technologies in Analysis and Audit|. In the discipline "Analysis of Economic Activity" students specializing in "Accounting and Taxation" write a term paper and undergo internship in the third year. As for effective management the result must be predictable, the management system of a modern enterprise must have as the subsystem the mechanism for processing and systematizing management information, transforming it into a management decision - the management analysis mechanism. And accounting experts will be able to adapt the management analysis mechanism to the purposes of the concrete enterprise.

The search for reserves for reducing costs should be based on the principle of combining product quality and the optimal level of resource costs for its production (Roehl-Anderson \& Bragg 2004, 193 - 198). The main reserves or sources of cost reduction are determined in the process of more efficient use of labor means, objects of labor and labor, and these processes could be adjusted by the accountant, as a result of gaining knowledge in the discipline "Modeling of optimization audit and consulting processes".

All the management functions that have been discussed are inextricably linked with controlling. With the help of control, as a rule, errors in the actions of certain employees are revealed: controlling is an expression of the functions of accounting 
and analysis, and also allows to identify and eliminate errors at each stage of management. Students- accountants acquire this knowledge by studying the disciplines "Control and Audit", "Audit", "Audit of Transnational Corporations", "Audit Consulting of International Contractual Relations".

During the execution of the accounting and control function, the following function appears - the regulatory function. This function is expressed in the direct impact of the accounting and control system on the production, that is, in its regulation. Unforeseen circumstances can cause an enterprise to deviate from its intended course. And if the management does not have the appropriate knowledge, it will be unable to find and correct negative deviations from the original plans before the enterprise is seriously damaged, not only the achievement of goals, and perhaps even the very survival of the enterprise, will be threatened.

Thus, accounting, analysis and control are the main functional components of the management system and are of practical importance not only for accountants, but also for managers of each level of enterprise management. They are the basis of the management information system, including the design of management accounting forms, budgeting, cost analysis, internal audits, calculation of all types of taxes and assessment of the taxation system desired for a given enterprise, etc. Without it, the functioning of enterprises and organizations of various industries and forms of ownership is impossible.

To provide accounting and control over the financial activities of enterprises; economic feasibility of actions; objective assessment of financial efficiency and legality of management decisions and their implementation; to develop financial forecasts and conduct strategic economic analysis; control the rational use of material, labor and financial resources; engage in financial, credit and settlement activities is possible only through knowledge of accounting, analysis and auditing. However, these tasks are able to perform not only accounting professionals. To successfully manage the enterprise, managers must not only have free knowledge of mathematics, management, macroeconomics, microeconomics, finance, but also financial analysis, accounting, management and auditing.

Reflecting on the future of the accounting profession on the eve of the Fourth Industrial Revolution, K. Gospodinova emphasizes that an accountant is a specialist who must decide what is the most suitable for the future development of an enterprise. He will determine the most effective path, and modern technologies will help to follow it easier (Gospodinova 2020, 675).

With regard to the future role of professional accountants, M. Pavlova identifies three trends. Firstly, keeping in mind the new business realities, the author notes that specialist accountants will have to use their competencies in an integrative way, going beyond their standard roles, to apply financial, managerial, tax and other knowledge. Secondly, accountants will need to improve and refine their skills in managing, analyzing and visualizing data and information. This way, they will be able really participate as a business partner within the enterprise. Thirdly, accountants will play the role 
of a key link between the huge volumes and flows of information and the enterprise management system. To achieve this goal, they must know the knowledge of business and technologies, and have developed analytical competencies. They must be able to turn the information received into the key business ideas in order to help management make informed strategic decisions (Pavlova 2020, 72).

\section{Conclusion}

So, in the modern world, the work of an accountant has become more than just the ability to work correctly with numbers. Now it is an interweaving of knowledge from various fields of activity (including jurisprudence and information technologies), which an experienced and far-sighted specialist seeks to master as quickly as possible. Thus, mastering knowledge from accounting disciplines is a process associated with the achievement of specific goals, which is of practical importance in the long term of a future specialist. Each student who has received a higher education in accounting has the opportunity, on the basis of the fundamental knowledge acquired at the university, to navigate in any practical situation while performing functional duties. Knowledge of accounting, analysis and audit gives the future specialist the skills and practical experience in solving applied problems related to the competencies of managers of different levels. The specified is the key to the effective and long-term functioning of an enterprise.

\section{REFERENCES}

Dohadaieva, T. M., 2012. Oblik, analiz i kontrol' vytrat na vyrobnytstvo j kal'kuliuvannia sobivartosti produktsii. Ekonomika. Finansy. Pravo. 8, 22 - 24. [in Ukrainian].

Dovhan', L. Ye., 2011, Stratehichne upravlinnia: navch. Posib. Kyiv: CUL. [in Ukrainian].

Garrison, R. H., Norren, E. W. \& Brewer, P. C., 2006. Managerial Accounting. - 11-th ed. Irwin, New York.

Gospodinova, K., 2020. Schetovodstvoto na praga na Chetvartata industrialna revolyutsiya. Ikonomicheskata nauka, obrazovanie i realna ikonomika: razvitie i vzaimodeystviya v digitalnata epoha. Sbornik $s$ dokladi ot Yubileyna mezhdunarodna nauchna konferentsiya $v$ chest na 100-godishninata ot osnovavaneto na Ikonomicheski universitet Varna. Tom III. Varna: Izdatelstvo „Nauka i ikonomika - Ikonomicheski universitet - Varna“, $671-676$.

Kobyliukh, O. Ya., 2012. Oschadlyve vyrobnytstvo iak kontseptsiia optymizatsii vyrobnychoho ta upravlins'koho protsesiv. Visnyk Natsional'noho universytetu "L'vivs'ka politekhnika": Lohistyka. 749, $43-49$ [in Ukrainian]. 
Lavryk, U. V., 2013. Suchasni pidkhody do upravlinnia vytratamy promyslovykh pidpryiemstv. Naukovi pratsi Kirovohrads'koho natsional'noho tekhnichnoho universytetu. Ekonomichni nauky. 24, 360 - 369. [in Ukrainian].

Pavlova, M., 2020. Preosmislyane badeshteto na schetovodnata profesiya. Sotsialno-ikonomicheski analizi. Poreditsa na Velikotarnovskiya universitet „Sv. Sv. Kiril i Metodiy“ - Stopanski fakultet. 1 (17), 66 - 72. [in Bulgarian].

Roehl-Anderson, J. M. \& Bragg, S. M., 2004. Controllership: The Work of the Managerial Accountant - 7-th ed. - Hoboken, New Jersey: John Wiley \& Sons, Inc.

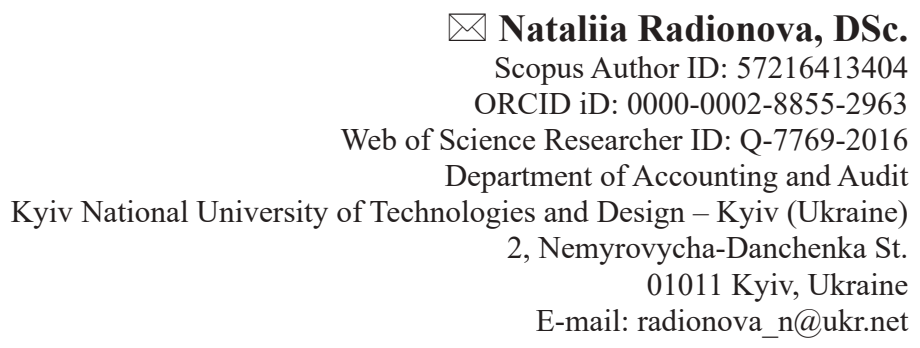

$\bowtie$ Dr. Radostina Stoyanova, Assist. Prof. ORCID iD: 0000-0003-2520-3560, RINC: SPIN-код: 2331-0595, Author ID: 443816

Web of Science Researcher ID: N-4756-2015 Institute for Bulgarian Language "Prof. L. Andreychin"

Bulgarian Academy of Sciences 52, Shipchenski Prohod Blvd., block 17

1113 Sofia, Bulgaria E-mail: r.stoyanova@ibl.bas.bg 